\title{
La incidencia de la Ley de régimen jurídico del sector público en los convenios urbanísticos de los municipios andaluces
}

\author{
Juan Fernando Granados Rodríguez
}

Técnico de Administración General, Ayuntamiento de Granada

Departamento de Derecho Administrativo. Universidad de Granada SUMARIO

I. LA APLICACIÓN DE LA NUEVA LEY DE RÉGIMEN JURÍDICO DEL SECTOR PÚBLICO A LOS CONVENIOS URBANÍSTICOS. II. EL CONTENIDO MÍNIMO DEL CONVENIO URBANÍSTICO. III. EL PROGEDIMIENTO DE APROBAGIÓN DE LOS CONVENIOS URBANÍSTICOS. IV. LA EXTINGIÓN DE LOS CONVENIOS URBANÍSTICOS. 1. Supuestos de extinción. 2. Efectos de la extinción. V. BIBLIOGRAFÍA

\section{RESUMEN}

La Ley de régimen jurídico del sector público regula los convenios, cuyos preceptos (arts. 48 y ss.), habida cuenta de su carácter básico, son plenamente aplicables a los convenios urbanísticos y, por consiguiente, inciden en su contenido, tramitación y extinción. Por esta razón, planteamos en este trabajo la armonización de la referida normativa con la legislación local y urbanística andaluza, con el fin de establecer el régimen jurídico unitario de los convenios urbanísticos municipales en la Comunidad Autónoma de Andalucía.

PALABRAS CLAVE: urbanismo, convenio, Administración local, régimen jurídico.

\section{ABSTRACT}

The Law on the Legal Regime of the Public Sector governs conventions, whose provisions (Article 48 et seq.), given their basic character, are fully applicable to urban agreements and therefore affect their content, processing and termination. For this reason, we propose in this work the harmonization of the aforementioned legislation with the local and urbanistic Andalusian legislation, in order to establish the unitary legal regime of municipal urban development agreements in Andalusia.

KEY WORDS: urban planning, agreements, local government, legal regime 


\section{LA APLICACIÓN DE LA NUEVA LEY DE RÉGIMEN JURÍDICO DEL SEGTOR PÚBLICO A LOS CONVENIOS URBANÍSTICOS}

La LRJSP ${ }^{1}$ dedica su Capítulo VI del Título Preliminar (arts. 48 y ss.) a los convenios. Estos preceptos, según la disposición final $14^{\text {a }}$ de la Ley, tienen la consideración de bases de régimen jurídico de las Administraciones públicas y, por tanto, se les atribuye el carácter de normas básicas².

La propia Ley señala en la exposición de motivos (apartado II in fine) que "se desarrolla un régimen completo de los convenios, que fija su contenido mínimo, clases, duración, y extinción y asegura su control por el Tribunal de Cuentas"3. Incluso, la disposición adicional octava de la LRJSP obliga a adaptar "Todos los convenios vigentes suscritos por cualquier Administración Pública o cualquiera de sus organismos o entidades vinculados o dependientes" a lo previsto en la Ley en el plazo de tres años desde su entrada en vigor ${ }^{4}$, que será automática respecto al plazo de vigencia para aquéllos que no lo tuvieran determinado o hubieran establecido una prórroga tácita por tiempo indefinido.

Ley 40/2015, de 1 de octubre, de régimen jurídico del sector público.

PIZARRO NEVADO, R., en El nuevo régimen jurídico del sector público, GOSALBEZ PEQUEÑO, H. (Dir.), Ed. Wolters Kluwer, Madrid (2016), pág. 137, afirma que este Capítulo "contiene un régimen jurídico común y de carácter básico para los convenios que suscriban las Administraciones Públicas, los organismos públicos y las entidades de derecho público vinculados o dependientes y las Universidades públicas entre sí o con sujetos de derecho privado".

Respecto a la regulación de los convenios en la LRJSP, puede consultarse BENSUSAN MARTÍN, M. P., "La nueva regulación de los convenios: la conversión en derecho positivo de una práctica administrativa", en Revista Andaluza de Administración Pública, no 96, Ed. IAAP, Sevilla (2016).

3 Como expone ARIAS MARTÍNEZ, M. A., en Comentarios a la Ley 40/2015 de Régimen Furídico del Sector Público, CAMPOS ACUÑA, C. (Dir.), Ed. Wolters Kluwer, Madrid (2017), pág. 253: "En el marco de este deficiente contexto normativo previo a la LRFSP, el Tribunal de Cuentas en sus informes de fiscalización denunció que esta regulación normativa del convenio, en ocasiones, daba lugar a prácticas en las que se soslayaba la aplicación de la legislación contractual en cuestiones en las que esta era la procedente y, asimismo, provocaba que la gestión de los fondos públicos discurriese por cauces jurídicamente inseguros; resistiéndose la aplicación de los principios de legalidad, eficiencia y economía. Los riesgos de estas prácticas le llevan a aprobar la moción 878/2010, de 30 de noviembre en la que propone «la configuración de un marco legal adecuado y suficiente para el empleo del convenio de colaboración por las Administraciones Públicas y la adopción de las medidas necesarias para un uso eficiente de los recursos públicos que se canalizan por esa vía»."

PIZARRO NEVADO, R., op. cit., pág. 137, indica que este régimen jurídico común se explica por la necesidad de encauzar una figura que ha ganado protagonismo en los últimos años por el incesante aumento de su número y por el peso que ha adquirido en el gasto público. A pesar de ello su regulación era poco precisa y se encontraba dispersa en infinidad de normas, por lo que resultaba difícil formular una definición consistente.

4 Sostiene PIZARRO NEVADO, R., op. cit., págs.. 151 y ss., que aunque la disposición adicional no diga nada, la adaptación ha de someterse al procedimiento de modificación del convenio previsto en el mismo o en la legislación aplicable, debiendo considerar las partes su objeto para determinar con precisión el fin común perseguido y los efectos jurídicos derivados, así como incorporar el contenido mínimo exigido por el art. 49 de la LRJSP. 
Concluimos, por tanto, que la LRJSP resulta de aplicación plena y sus disposiciones, en los supuestos habilitantes para la suscripción de los convenios urbanísticos regulados en la legislación urbanística y de régimen local, consecuentemente, han de ser respetadas al aplicar su régimen jurídico especial ${ }^{5}$.

Con carácter general, la LRJSP especifica, en su art. 48.1, que las Administraciones públicas (entendidas, en lo sucesivo, como éstas, sus organismos públicos y entidades de derecho vinculados o dependientes, así como las Universidades públicas) podrán suscribir, en el ámbito de sus respectivas competencias, convenios con sujetos de derecho público y privado, sin que ello pueda suponer la cesión de la titularidad de la competencia.

En su art. 47.2.c), enumera la LRJSP, como un tipo de convenio, el firmado entre una Administración pública (al caso, Ayuntamiento) y un sujeto de Derecho privado, además del resto de tipos detallados, como son: los convenios administrativos (inter e intra), contemplados en las letras a) y b) del precepto, así como otros convenios (letra d).

También la LPACAP ${ }^{6}$, con carácter básico en este tema (disposición final primera), recoge, en su art. 86.1 (terminación convencional) ${ }^{7}$, la posibilidad de celebrar convenios con personas tanto de Derecho público como privado, siempre que no sean

5 En este mismo sentido, MÚZQUIZ JIMÉNEZ I., "Los convenios administrativos en la Ley 40/2015 y su impacto sobre los convenios urbanísticos", Revista del sector inmobiliario Inmueble, $\mathrm{n}^{\circ} 171$, Ed. Difusión Jurídica y Temas de Actualidad, Madrid (2017).

ARIAS MARTÍNEZ, M. A., op. cit., pág. 258, asevera que, a partir de la entrada en vigor de la LRJSP, se aplican a todas las Administraciones públicas sus arts. 47 a 53, incluida, por tanto, la local.

6 Ley $39 / 2015$, de 1 de octubre, de procedimiento administrativo común de las Administraciones públicas.

El art. 48.9 de la LRJSP dispone: "Las normas del presente Capitulo no serán de aplicación a las encomiendas de gestión y los acuerdos de terminación convencional de los procedimientos administrativos."

Critica ARIAS MARTÍNEZ, M. A., op. cit., págs.. 258 y ss., esta decisión del legislador, toda vez que los acuerdos de terminación convencional (a diferencia de las encomiendas de gestión) tienen sustantividad propia y están regulados en el art. 86 de la LPACAP.

PFLEUGER TEJERO, E., Régimen jurídico del Sector Público y Procedimiento Administrativo Común, RECUERDA GIRELA, M. A. (Dir.), Ed. Thomson Reuters, Cizur Menor (2016), pág. 1255, mantiene que no son aplicables a los convenios las normas relativas a los acuerdos de terminación convencional de los procedimientos administrativos.

ALMEIDA CERREDA, M., en Comentarios a la Ley 39/2015 de procedimiento administrativo común de las Administraciones públicas, GAMPOS ACUÑA, C. (Dir.), Ed. Wolters Kluwer, Madrid (2017), pág. 576 y ss., explica que el precepto regula acuerdos entre Administraciones o entre una Administración y uno o varios particulares, que corresponden a dos tipos: a) los "convenios resolutorios", finalizadores de los procedimientos administrativos (v. gr., art. 24 de la Ley de 16 de diciembre de 1954, de expropiación forzosa); y b) los "convenios de trámite" (o "intraprocedimentales"), insertos en el seno de procedimientos con carácter previo a la resolución que les pone fin, que, a su vez se dividen en "vinculantes" (predeterminan de forma rígida el contenido de la resolución que pone término al procedimiento; p. ej., art. 52 de la Ley 15/2007, de 3 de julio, 
contrarios al ordenamiento jurídico ni versen sobre materias no susceptibles de transacción y tengan por objeto satisfacer el interés público que tienen encomendado, con el alcance, efectos y régimen jurídico específico que, en su caso, prevea la disposición que los regule, pudiendo tales actos insertarse en los procedimientos administrativos con carácter previo, vinculante o no, a la resolución que les ponga fin; sin alteración de las competencias atribuidas a los órganos administrativos, ni de las responsabilidades correspondientes a las autoridades y funcionarios, relativas al funcionamiento de los servicios públicos (art. 86.4 de la LPAGAP).

De forma similar se regula la cuestión en el art. 111 del TR-86 ${ }^{8}$ y al convenio también se hace mención en la referencia contenida en el art. 6.2 de la LCSP ${ }^{9}$, cuando excluye de su ámbito de aplicación los convenios que, con arreglo a las normas específicas que los regulan, celebre la Administración con personas físicas o jurídicas

de defensa de la competencia) y "no vinculantes" (art. 85 del R. D. Leg. 2/20155, de 5 de septiembre, Texto refundido de la Ley de puertos del Estado y de la Marina Mercante).

Aclara, además, que, a efectos de precisar su régimen jurídico, estos acuerdos de voluntades no constituyen ni convenios de colaboración (arts. 4.1, letras c y d, del R. D. Leg. 3/2011, de 14 de noviembre, Texto refundido de la Ley de contratos del sector público, y arts. 49 a 53 de la LRJSP), ni convenios de transacción (arts. 1809 y ss. del Código Civil), por lo que, en ningún caso, les serán aplicables las reglas establecidas para estas figuras.

RIVERO ORTEGA, E., Instituciones de procedimiento administrativo común. Novedades de la Ley 39/2015, VV.AA., Ed.Juruá, Lisboa (2016), pág. 216, argumenta que la declaración de voluntad de la Administración consistente en terminar convencionalmente un procedimiento no deja de ser un acto administrativo; no se trata de un acuerdo o convenio sino de una decisión cuya procedencia es, sin embargo, convencional. La Administración decide en última instancia con plena potestad y soberanía, no obstante dicha decisión haya venido aconsejada por el previo consenso alcanzado con los interesados y, por supuesto, con pleno respeto al interés público y al ordenamiento jurídico.

Añade este autor (pág. 218) que las disposiciones contenidas en los arts. 47 y ss. de la LRJSP quedan expresamente excluidas de aplicarse a los supuestos de terminación convencional de los procedimientos. A su juicio, esto determina la falta de regulación de los acuerdos convencionales (art. 86 de la LPACAP) y genera una inseguridad jurídica innecesaria, puesto que, en particular, los trámites preceptivos regulados en el art. 50 de la LRJSP hubieran sido una buena referencia para fijar las condiciones mínimas de las terminaciones convencionales. régimen local.

R. D. Leg. 781/1986, de 18 de abril, Texto refundido de disposiciones vigentes en materia de

9 Ley $9 / 2017$, de 8 de noviembre, de contratos del sector público, por la que se transponen al ordenamiento jurídico español las Directivas del Parlamento Europeo y del Consejo 2014/23/UE y 2014/24/UE, de 26 de febrero de 2014.

Explica PFLUEGER TEJERO, E., op. cit., pág. 1255, que el art. 4.2 del R. D. Leg. 3/2011, de 14 de noviembre, Texto refundido de la Ley de contratos del sector público (TRLCSP) remite a las normas especiales para la regulación de los contratos, negocios y relaciones jurídicas enumerados en el apartado anterior, si bien se le aplicarán los principios de esta Ley para resolver las dudas y lagunas que pudieran presentarse (actualmente la referencia ha de entenderse hecha al art. 4 de la LCSP). Para el Tribunal de Cuentas se trata de los principios de publicidad, transparencia, concurrencia, igualdad y no discriminación, y si suponen compromisos financieros, los de estabilidad presupuestaria y control del gasto y de eficiencia en utilización de los fondos públicos 
sujetas al derecho privado, siempre que su objeto no esté comprendido en el de los contratos regulados en esta Ley o en normas administrativas especiales.

La definición de los convenios está contenida en el art. 47 de la LRJSP, esto es, los acuerdos con efectos jurídicos adoptados por las Administraciones públicas, los organismos públicos y entidades de derecho público vinculados o dependientes o las Universidades públicas entre sí o con sujetos de derecho privado para un fin común. De conformidad con el apartado primero del precepto, los convenios no podrán tener por objeto prestaciones propias de los contratos; en tal caso, su naturaleza y régimen jurídico se ajustará a lo previsto en la legislación de contratos del sector público ${ }^{10}$.

Reseña SENDÍN ${ }^{11}$ que el convenio urbanístico es, por una parte, un acuerdo de voluntades, pero también es, por otro, un instrumento dirigido al ejercicio de potestades administrativas que integran la función pública urbanística, en definitiva, una forma de administrar.

Según CANO MURCIA ${ }^{12}$, los convenios urbanísticos son acuerdos de voluntades entre la Administración y personas físicas o jurídicas, públicas o privadas titulares de intereses urbanísticos (promotores, empresas físicas, juntas de compensación, vecinos, etc.) que tienen su funcionamiento en el principio de participación de los particulares en el urbanismo y la capacidad negocial de la Administración, celebrados con la finalidad de completar a la Ley, en aquellos supuestos en que la regulación legal está inacabada o prevé expresamente la llamada al convenio, resolviendo de esta forma los problemas que las insuficiencias que la legislación urbanística plantea y dando satisfacción a la participación de los ciudadanos en la definición de su digna calidad de vida ${ }^{13}$.

10 ARIAS MARTÍNEZ, M. A., op. cit., págs. 255 y 256, marca tres elementos esenciales del convenio (que lo diferencian del contrato), a saber: a) los efectos jurídicos proceden de la voluntad de todas las partes (no de una de ellas); b) la causa de la aportación será "un fin común" (no la prestación o promesa de una cosa o servicio por la otra parte); y c) ese fin habrá de ser de interés público.

PIZARRO NEVADO, R., op. cit., pág. 139, subraya que un convenio trata de establecer una colaboración institucional para llevar a cabo una actuación con el fin de alcanzar objetivos compartidos.

Seguidamente añade que la diferencia entre convenio y contrato no puede extraerse exclusivamente del objeto material; por tanto, hay convenio si, concurriendo todas las condiciones, el objeto no fuera contractual y también puede formalizarse un convenio si, siendo el objeto contractual, falta una nota esencial de la definición del contrato como puede ser la onerosidad.

11 SENDÍN GARCÍA, M. A., Régimen jurídico de los convenios urbanísticos, Ed. Comares, Granada (2008), pág. 18, donde también hace una sistemática clasificación de los convenios urbanísticos (págs. 28 y ss.).

12 CANO MURCiA, A., Teoría y práctica del convenio urbanístico, Ed. Aranzadi, Cizur Menor (2005), págs. 25 y ss.

13 LAGO NÚNẼE, G., en Los convenios urbanísticos de Andalucía (2010), recoge diversas definiciones efectuadas por la doctrina y una exhaustiva clasificación de los convenios.

http://www.academia.edu/8618441/LOS_CONVENIOS_URBAN\%C3\%8DSTICOS_EN_ ANDALUC $\%$ C3 $\% 8 D A$ 
La STSJ ${ }^{14}$ de Andalucía de 3 de enero de $2001^{15}$ define los convenios urbanísticos como los instrumentos de acción concertada que aseguran a los entes públicos una actuación urbanística eficaz, la consecución de objetivos concretos y la ejecución efectiva de actuaciones beneficiosas para el interés general, cuya finalidad no es otra que complementar las determinaciones legales en materia de urbanismo, posibilitando el acuerdo de las partes afectadas por el planeamiento, eliminando puntos de fricción y los obstáculos que pueda ocasionar una determinada actuación urbanística ${ }^{16}$.

Según el art. 48.3 de la LRJSP, la suscripción de convenios deberá mejorar la eficiencia de la gestión pública, facilitar la utilización conjunta de medios y servicios públicos, contribuir a la realización de actividades de utilidad pública y cumplir con la legislación de estabilidad presupuestaria y sostenibilidad financiera ${ }^{17}$. El art. 86.1 de la LPACAP menciona como objeto "satisfacer el interés público" encomendado a las Administraciones públicas.

A este respecto, en Andalucía, el art. 2 de la LOUA $^{18}$ expone que la actividad urbanística es una función pública que comprende, entre otros, la planificación, organización, dirección y control de la ocupación y utilización del suelo, a la vez que señala, como potestades de las Administraciones públicas, cualesquiera que sean necesarias para la efectividad de los fines de la actividad urbanística.

La LOUA prevé, en su art. 5.2, que las Administraciones competentes en materia de ordenación urbanística podrán suscribir convenios urbanísticos con particulares con la finalidad de establecer los términos de colaboración para el mejor y más eficaz desarrollo de la actividad urbanística. En su art. 30.2 (dedicado a los convenios urbanísticos de planeamiento), dispone que los Ayuntamientos y la Administración autonómica (además de convenios interadministrativos, apartado primero del precepto) podrán suscribir con cualesquiera personas, públicas o privadas, sean o no propietarias de suelo, convenios urbanísticos relativos a la formación o innovación de un instrumento de planeamiento ${ }^{19}$. De forma parecida, para determinar las condi-

14 Sentencia del Tribunal Superior de Justicia.

15 RJCA 2001/585.

16 Según la STSJ de Cataluña de 9 marzo 2006 (JUR 2007\49944), se limita a llegar a un acuerdo entre las partes al objeto de facilitar la gestión, allanando los problemas que se presenten, teniendo por objeto la satisfacción del interés público, "pues tal instrumento jurídico, aun atendiendo en ocasiones a finalidades privadas (...), no constituye, en su esencia, más que una manera de satisfacción del interés público supraindividual, al que debe tender toda actividad de cualquier Administración Pública, en aras a lograr la mejor ordenación urbanística posible".

17 Ley 2/2012, de 27 de abril, de estabilidad presupuestaria y sostenibilidad financiera.

18 Ley 7/2002, de 17 de noviembre, de ordenación urbanística de Andalucía.

19 No son en sí mismos actos de alteración del planeamiento, sino actos independientes, que tienen un carácter preparatorio de esa alteración, según SENDÍN GARCÍA, M. A., op. cit., pág. 30. 
ciones y los términos de la gestión y ejecución del planeamiento urbanístico en vigor, prevé el art. 95.1 de la LOUA la celebración de convenios urbanísticos de gestión ${ }^{20}$.

En conclusión, la regulación establecida en la LRJSP para los convenios (preceptos con carácter de norma básica) es aplicable a aquéllos de naturaleza urbanística y habrá de cohonestarse con la normativa propia urbanística al respecto. En el ámbito de la Comunidad Autónoma andaluza estos convenios urbanísticos, dado que constituyen legalmente una manifestación de la función pública urbanística a través del ejercicio de potestades de las Administraciones públicas, dan cumplimiento a los presupuestos exigidos por las Leyes estatales, es decir, satisfacen el interés público ${ }^{21}$ y contribuyen primordialmente a la realización de una actividad de utilidad pública, sin menoscabo de mejorar la eficacia de la gestión pública y que pudieran, en ciertos supuestos, facilitar la utilización conjunta de medios y servicios públicos; todo ello, claro está, con estricto sometimiento a la legislación de estabilidad presupuestaria y sostenibilidad financiera (art. 48.3 de la LRJSP).

Por último, al tenor del art. 61 del TRLSRU ${ }^{22}$, los convenios urbanísticos tienen carácter jurídico administrativo, que es también reconocido expresamente por el art. 30 de la LOUA, para los convenios urbanísticos de planeamiento, y por el art. 95.2 de esta Ley, para los de gestión. De la naturaleza administrativa de los convenios se deriva la competencia de la jurisdicción contencioso-administrativa para conocer de las controversias suscitadas ${ }^{23}$. El convenio constituye una realidad dotada de entidad sustantiva propia, susceptible, por ello, de ser impugnado por separado, en cuanto no puede ser reducido al papel de un mero acto de trámite del procedimiento en que se adopte el acto administrativo o reglamento a cuya preparación se dirige ${ }^{24}$. La acción

$20 \quad$ El Tribunal Supremo, en Sentencia de 15 de marzo de 1997 (RJ 1977/1677), distingue entre ambos convenios: "A diferencia de los Convenios de gestión urbanística, para la gestión o ejecución de un planeamiento ya aprobado, los Convenios de planeamiento, como el que se enjuicia, constituyen una manifestación de una actuación convencional frecuente en las Administraciones Públicas, que tiene por objeto la preparación de una modificación o revisión del planeamiento en vigor".

La LRJSP (art. 48.3) usa la expresión "actividades de utilidad pública”y el art. 86.1 de la LPACAP sí utiliza literalmente el término "interés público".

En palabras de SENDÍN GARCÍA, M. A., op. cit., pág. 151 y ss., “interés público y determinado: aquél que determina y al que se subordina la atribución de la potestad administrativa de que se trate a la Administración", quien también indica que en los convenios urbanísticos la finalidad concreta para la que se otorga la potestad de celebrarlos es la colaboración en el mejor y más eficaz desarrollo de la actividad urbanística; sin embargo, esto no impide que constituyan una vía válida para la persecución de cualquier tipo de finalidad, específicamente urbanística o no, en la que subyazca un interés público relevante, que pueda lograrse a través de una adecuada política urbanística.

22 R. D. Leg. 7/2015, de 30 de octubre, Texto refundido de la Ley de suelo y rehabilitación urbana.

23 SENDÍN GARCÍA, M. A., op. cit., págs. 234 y ss.

24 No participan de naturaleza reglamentaria y, por tanto, no pueden ser objeto de recurso indirecto, al amparo de la Sentencia del Tribunal Supremo de 9 de marzo de 2001 (RJ 2001/2736). 
pública $^{25}$ en defensa de la legalidad urbanística (art. 62 del TRLSRU) es también extensible al ámbito de los convenios urbanísticos.

\section{EL GONTENIDO MÍNIMO DEL GONVENIO URBANÍSTICO}

Para determinar el contenido mínimo del convenio urbanístico debemos atender conjuntamente a lo dispuesto en la LRJSP (art. 49) ${ }^{26}$, LPACAP (art. 86.2) y LOUA (arts. 30 y 95). De ahí, se desprenden los siguientes extremos necesarios de su contenido:

a) Sujetos que suscriben el convenio y capacidad jurídica con que actúa cada una de las partes:

La LOUA hace referencia a los "otorgantes" (art. 30.2, regla 4", y art. 95.2, regla $3^{\mathrm{a}}$ ) con motivo del contenido del acuerdo de aprobación. Sin embargo, la LPACAP (art. 86.2) distingue entre "partes intervinientes" y "ámbito personal", puesto que lógicamente las personas que suscriben el convenio no tienen por qué coincidir con el grupo de personas sobre el que va a surtir efectos el contenido del convenio (aunque tratándose de convenios urbanísticos, el ámbito personal quedará muy diluido o, incluso, no existirá, ya que el ámbito primordial será el territorial, o sea, el suelo: terreno, finca, unidad apta, parcela o solar).

Queda claro que una de las partes siempre será una Administración pública (Ayuntamiento, en este caso), que debe actuar exclusivamente en el ámbito de sus actuaciones. No será posible, obviamente, que el convenio vincule a persona pública distinta a la que lo celebra en el ejercicio de sus competencias o a terceros privados no firmantes del convenio.

El sujeto afectado por el ejercicio de las potestades urbanísticas normalmente será un sujeto privado o varios (individual o colectivo), sin menoscabo de que puedan ser una o varias Administraciones públicas (por afección de sus intereses) o, incluso, una entidad urbanística colaboradora (p. ej., junta de compensación o asociación administrativa de propietarios).

Para el supuesto de que se produzca la transmisión de la titularidad de los derechos afectados por el ejercicio de la potestad urbanística, postula SENDÍN ${ }^{27}$

25 Puede consultarse GRANADOS RODRÍGUEZ, J. F., "La revisión de actos nulos mediante el ejercicio de la acción pública en materia de urbanismo: una herramienta más para combatir las ilegalidades urbanísticas", en Revista de Derecho urbanístico y medio ambiente, no 228, Madrid (2006).

26 PIZARRO NEVADO, R., op, cit., pág. 143, precisa que este artículo viene a cubrir una de las carencias que siempre se ha reprochado a la regulación de los convenios, como era la imprecisión sobre su contenido.

SENDÍN GARCÍA, M. A., op. cit., pág. 95. 
que la subrogación de las obligaciones adquiridas se produce cuando se trata de la transmisión de deberes legales y de compromisos derivados exclusivamente del convenio inscritos en el Registro. En cualquier caso, se debe entender que cuando se verifica una transmisión de los derechos afectados por el convenio, el otorgante originario queda obligado a comunicar a la Administración los datos identificativos de los nuevos titulares de los terrenos. No obstante, a nuestro juicio, debería incluirse un plazo para ello, así como la obligación de comunicar al tercero la existencia del convenio urbanístico.

b) Ámbito funcional y competencia en que se fundamenta la actuación de la Administración pública:

La LRJSP enumera sólo la "competencia", pero la LPACAP exige un aspecto más amplio, que la engloba, como es el "ámbito funcional", que equivaldrá a la función pública urbanística para los convenios de esta naturaleza.

El convenio, en ningún caso, puede suponer la cesión de la titularidad de la competencia que corresponda a la Administración pública (art. 48.1 de la LRJSP).

c) Objeto del convenio y actuaciones que debe realizar cada sujeto para su cumplimiento ${ }^{28}$, indicando, en su caso, la titularidad de los resultados obtenidos ${ }^{29}$.

La LPACAP menciona el "ámbito funcional" y la LOUA se limita a indicar el "objeto" (dentro del acuerdo de aprobación); si bien parece totalmente lógico que el convenio contenga, no sólo el objeto concreto, sino todo el régimen de derechos y obligaciones de las partes.

Los convenios urbanísticos no pueden actuar como sustitutivos de los actos administrativos precisos (licencias u otros títulos habilitantes, procedimiento de alteración del planeamiento, régimen de responsabilidad patrimonial, ejercicio de competencias, etc. $)^{30}$.

d) Obligaciones y compromisos económicos asumidos por cada una de las partes, si los hubiera, indicando su distribución temporal por anualidades y su imputación concreta al presupuesto correspondiente de acuerdo con lo previsto en la legislación presupuestaria:

28 LUQUE REGUEIRO, F., en Régimen jurídico.., RECUERDA GIRELA, M. A. (Dir.), op. cit., pág. 1262, colige de esta expresión que todas las partes han de comprometerse a determinadas actuaciones, no bastando que una de las partes se limite a la mera financiación de la actución desarrollada por la otra.

29 SENDÍN GARCÍA, M. A., op. cit., págs. 108, 109 y 126, enumera los siguientes requisitos del objeto: lícito, posible y determinado (arts. 1271 y ss. del Código Civil), sobre bienes o prestaciones presentes o futuras, incluso con carácter traslativo (transmisión de bienes - y derechos, añadiríamos nosotros-, siempre que sean disponibles).

30 SENDÍN GARCÍA, M. A., op. cit., pág. 169 y ss. 
Es una exigencia expresa de la LRJSP que responde a los requisitos y procedimiento exigidos por el régimen presupuestario de la Administración.

Deben tenerse en cuenta las prescripciones que la LOUA contempla para el caso de sustituciones en metálico. Por ejemplo, la percepción de cantidad económica a favor de la Administración contemplada en las estipulaciones del convenio urbanístico de planeamiento, cuando derive de la sustitución en metálico de los terrenos donde se localice el aprovechamiento urbanístico que corresponda a la Administración en concepto de participación de la comunidad en las plusvalías urbanísticas, no podrá exigirse ni efectuarse hasta la aprobación del instrumento de planeamiento en que se justifique dicha sustitución en metálico (art. 30.3 de la LOUA). El apartado segundo de este precepto obliga a que, en los casos previstos legalmente de cesión del aprovechamiento urbanístico mediante pago de cantidad sustitutoria en metálico, el convenio incluya la valoración de estos aprovechamientos realizada por los servicios de la Administración (cantidad que se integrará en el Patrimonio Municipal de Suelo, como también mandata el art. 95.2 para los convenios de gestión).

e) Ámbito territorial del convenio:

La LPACAP señala expresamente este requisito, mientras que la LOUA (arts. 30.2 y 95.2) utiliza simplemente la expresión de "ámbito".

El art. 38 del TRLCI ${ }^{31}$ exige que la referencia catastral de los bienes inmuebles (acreditada mediante alguno de los documentos relacionados en el art. 41) figure en los expedientes y resoluciones administrativas y en los documentos donde consten los hechos, actos o negocios de trascendencia real relativos al dominio y demás derechos reales, o cualesquiera otros documentos relativos a los bienes inmuebles que se determinen reglamentariamente

Asimismo, es aconsejable la acreditación y constancia de los datos registrales del bien inmueble al que afecte el convenio urbanístico; más aún si se pretende el acceso del documento administrativo al Registro de la Propiedad.

f) Consecuencias aplicables en caso de incumplimiento de las obligaciones y compromisos asumidos por cada una de las partes y, en su caso, los criterios para determinar la posible indemnización por el incumplimiento ${ }^{32}$.

31 Real Decreto Legislativo 1/2004, de 5 de marzo, por el que se aprueba el Texto refundido de la Ley del Catastro Inmobiliario

32 LUQUE REGUEIRO, F., op. cit., pág. 1267, opina que la previsión expresa de tal indemnización no puede erigirse en un requisito de exigibilidad, pues entiende que serán de aplicación supletoria, si nada se contemplara en el convenio, los principios generales de responsabilidad contractual. 
g) Mecanismo de seguimiento, vigilancia y control de la ejecución del convenio y de los compromisos adquiridos por los firmantes:

Al tenor del art. 49 de la LRJSP, este mecanismo resolverá los problemas de interpretación y cumplimiento que se planteen ${ }^{33}$. Deducimos de la redacción de los arts. 51.2.c) y 52.3 de la LRJSP que al frente del mismo debe haber un responsable (unipersonal) o una comisión (colegiado) ${ }^{34}$. En nuestra opinión, debería corresponder a un órgano administrativo con posibilidad de adoptar decisiones ad extra. Al efecto, en lo concerniente a la Administración local para municipios de gran población, recordamos que el art. 130.1 de la LBRL atribuye carácter de órgano directivo a los directores generales $\mathrm{u}$ órganos similares que culminen la organización administrativa dentro de cada una de las grandes áreas o concejalías, sin perjuicio de aquellos otros que se creen dentro de la propia organización ${ }^{35}$.

SENDÍN ${ }^{36}$ propugna que el convenio urbanístico debe ser interpretado de conformidad con las normas que lo rigen o regulan los convenios con carácter general, a falta de ellas, por las de contratación administrativa y, en su defecto, por el Derecho civil, sin olvidar las normas administrativas que rigen el ejercicio de la potestad urbanística (entre ellas, el planeamiento).

h) Régimen de modificación del convenio, que, a falta de regulación expresa, requerirá acuerdo unánime de los firmantes ${ }^{37}$.

i) Plazo de vigencia del convenio:

Deberá ser de duración determinada no superior a cuatro años, salvo previsión normativa superior, aunque, en cualquier momento antes de su finalización, los fir-

33 ARIAS MARTÍNEZ, M. A., op. cit., pág. 268, mantiene que nada impide que, en ejercicio del derecho fundamental a la tutela judicial efectiva y previa reclamación ante el mecanismo de control establecido en el convenio, las posibles controversias que surjan en la gestión o ejecución del acuerdo se sustancien ante los tribunales de la jurisdicción contencioso-administrativa. Incluso, las partes pueden presentar un recurso por inactividad en los supuestos en los que no se lleven a cabo todas o alguna de las prestaciones establecidas en el convenio y también cabría la interposición del recurso de anulabilidad contra aquellos actos administrativos dictados con ocasión de su gestión o ejecución.

34 ARIAS MARTÍNEZ, M. A., op. cit., pág. 268, piensa que con la nueva regulación su creación reviste carácter imperativo, pero no se determina su configuración, de modo que puede tratarse de un órgano mixto en el que participen representantes de cada parte, o bien de un órgano arbitral independiente.

35 Véase GRANADOS RODRÍGUEZ, J. F., "La dirección pública profesional y la creación de órganos directivos en las administraciones locales de régimen común", en Revista Iberoamericana de Gobierno Local, nº 5, Ed. CIGOB, Granada (2013).

36 SENDÍN GARCÍA, M. A., op. cit., págs.. 226 y ss.

37 SENDÍN GARCÍA, M. A., op. cit., págs. 114 y ss, expone que la Administración pública puede hacer uso de los poderes de modificación y resolución unilateral que le otorga el ordenamiento jurídico para la salvaguarda del interés público; ahora bien, dicha posibilidad está estrictamente limitada por la concurrencia de un interés público que justifique ese ius variandi. 
mantes podrán acordar unánimemente su prórroga por un período de hasta cuatro años adicionales ${ }^{38}$ o su extinción ${ }^{39}$.

La regulación de la vigencia del convenio en estos términos es una novedad de la LRJSP, si bien tanto la LPACAP como la LOUA (arts. 30.2 y 95.2) especifican el "plazo de vigencia" entre el contenido del contrato y del acuerdo de aprobación, respectivamente.

Ha de tenerse en cuenta que la disposición adicional octava de la LRJSP proclama la adaptación automática del plazo de vigencia para los convenios que a la entrada en vigor de la Ley no lo tuvieran determinado o tuvieran establecida una prórroga tácita por tiempo indefinido, en cuyo caso aquél será de cuatro años contados desde la entrada a vigor de la LRJSP.

Plantea SENDÍN ${ }^{40}$ la posibilidad de someter a condición (suspensiva o resolutoria) el convenio urbanístico, incluso con reversión de donaciones en determinados supuestos.

Los convenios o negocios jurídicos que el promotor de la actuación celebre con la Administración correspondiente no podrán establecer obligaciones o prestaciones adicionales ni más gravosas que las que procedan legalmente, en perjuicio de los propietarios afectados, según dispone el art. 9.8 del TRLSRU, considerándose nula la cláusula que contravenga estas reglas.

Los convenios urbanísticos de planeamiento (art. 30 de la LOUA) sólo tendrán el efecto de vincular a las partes para la iniciativa y tramitación del pertinente procedimiento sobre la base del acuerdo respecto de la oportunidad, conveniencia y posibilidad de concretas soluciones de ordenación, y en ningún caso vincularán a las Administraciones públicas en el ejercicio de sus potestades ${ }^{41}$

38 Entiende ARIAS MARTÍNEZ, M. A., op. cit., pág. 267, que no está prevista la sucesión de prórrogas, sino solamente una; de manera que no es posible alterar esta previsión por acuerdo de las partes firmantes del acuerdo.

39 El Pleno del Tribunal Constitucional, por Providencia de 19 de julio de 2016, acordó admitir a trámite el recurso de inconstitucionalidad núm. 3774-2016, contra el art. 49 h), párrafo segundo, y por conexión, la disposición adicional octava, entre otros (Boletín Oficial del Estado nº 184, de 1 de agosto de 2016).

40 SENDÍN GARCÍA, M. A., op. cit., págs. 116 y ss.

${ }^{41}$ SENDÍN GARCÍA, M. A., op. cit., pág. 173, dice que si la Administración, al tramitar el oportuno procedimiento administrativo para la modificación del planeamiento, descubre una solución más favorable para el interés público que la plasmada en el convenio urbanístico previo, deberá optar por ella; no generan, por tanto, una obligación de resultado. Posteriormente, este autor (págs. 193 y ss.) apunta que cuando el convenio implica pactos relativos al ejercicio de potestades públicas indisponibles, la Administración queda obligada tan sólo a un diligente y leal intento de llevar a la práctica lo pactado. 


\section{EL PROCEDIMIENTO DE APROBACIÓN DE LOS GONVENIOS URBANÍSTICOS}

El procedimiento administrativo para la aprobación de los convenios urbanísticos en el ámbito municipal debe estructurarse con la integración de los preceptos de carácter general dedicados a los convenios en la LRJSP y LPACAP, de la regulación especial de los convenios urbanísticos establecida en la LOUA, así como de la normativa reguladora del régimen local $\left(\mathrm{LBRL}^{42}\right)$.

La tramitación, celebración y cumplimiento de los convenios urbanísticos de planeamiento se regirán por los principios de transparencia ${ }^{43}$ y publicidad (arts. 30.4 de la LOUA). Igual prescripción contiene el art. 95.2 de la LOUA para los convenios urbanísticos de gestión; si bien añade expresamente la fase de "negociación", que, entendemos, existirá también en los de planeamiento, regida por los mismos principios $^{44}$.

Los trámites correspondientes para la aprobación del convenio urbanístico se pueden resumir en los siguientes $\operatorname{pasos}^{45}$ :

a) Inicio:

Al amparo de lo dispuesto en el art. 66 de la LPACAP, el procedimiento puede iniciarse a solicitud del interesado. Ahora bien, entendemos que la propuesta a la Administración por parte del particular para suscribir finalmente un convenio urbanístico comporta un ejercicio del derecho de petición. Ello supone que no tiene

42 Ley $7 / 1985$, de 2 de abril, reguladora de bases de régimen local.

43 El art. 8 de la Ley 19/2013, de 9 de diciembre, de transparencia, acceso a la información pública y buen gobierno, obliga a hacer pública la relación de los convenios suscritos con repercusión económica o presupuestaria, con mención de las partes firmantes, su objeto, plazo de duración, modificaciones realizadas, obligados a la realización de las prestaciones y, en su caso, las obligaciones económicas convenidas.

44 Como señala SENDÍN GARCÍA, M. A., op. cit., pág. 263, parte de la doctrina demanda también la inclusión del principio de concurrencia, pero, coincidimos con este autor, en que no es aplicable en muchos casos, cuando sólo determinadas personas son las que pueden ofrecer lo que requiere la Administración o sólo ellas son las interesadas en el resultado final de lo convenido (p. ej., actuación urbanística en una parcela concreta).

El propio Tribunal Supremo, en Sentencia de 15 de marzo de 1997 (RJ 1997/1677), ha declarado que la naturaleza de la actuación que se prepara en el convenio no es idónea para una licitación cuando el particular propone la modificación del plan y firma el convenio no en calidad de contratista sino como consecuencia de su condición de propietario.

45 SENDÍN GARCíA, M. A., op. cit., págs.. 256 y ss., recalca que la obligación de tramitar el procedimiento legalmente establecido no tiene un carácter puramente formal y debe producir una auténtica sustanciación de éste, dotada de capacidad de influencia en la decisión final; toda vez que si en el transcurso del procedimiento la Administración llega a la conclusión de que hay una solución más favorable al interés público que la inicialmente considerada en el convenio, deberá adoptar esa decisión más favorable para un mejor servicio del interés público. 
efectos el silencio administrativo estimatorio, en su caso, sino el desestimatorio, ex art. 24.1 de la LPACAP. La decisión de la Administración pública a la tramitación del convenio urbanístico puede materializarse en un acuerdo de admisión a trámite.

Tampoco consideramos que se pueda iniciar de oficio el procedimiento (arts. 58 y ss. de la LPACAP), puesto que no se puede imponer al particular u otra Administración pública el otorgamiento de su consentimiento al convenio. En nuestra opinión, podría orientarse esta fase como mera actuación previa (art. 55 LPACAP), a fin de obtener la conformidad de la otra parte para la tramitación del convenio urbanístico (o sea, la denominada "negociación” en el art. 95 de la LOUA) y, por tanto, determinar la conveniencia de iniciar el procedimiento.

b) Memoria justificativa:

Como trámite preceptivo ${ }^{46}$, sin perjuicio de las especialidades que la legislación autonómica prevea, el art. 50 de la LRJSP exige que el convenio se acompañe de una memoria justificativa donde se analice su necesidad y oportunidad ${ }^{47}$, su impacto económico $^{48}$, el carácter no contractual de la actividad en cuestión ${ }^{49}$, así como el cumplimiento de lo previsto en esta Ley.

El fundamento de los convenios urbanísticos reside en los principios de participación de los ciudadanos en el urbanismo (art. 5.2 de la LOUA) y de eficacia de la Administración (art. 3.1 de la LRJSP), así como encuentran justificación en un pro-

46 PIZARRO NEVADO, R., op. cit., pág. 146, apunta que debe ser la legislación reguladora de cada tipo de convenio la que determine el procedimiento que se debe seguir y cómo se inserta en el mismo la memoria o trámite que permita acreditar el cumplimiento de las exigencias correlativas. Señala también (pág. 145) que, con carácter previo a la suscripción de un convenio, coincidiendo con la fase de negociación, las Administraciones públicas están obligadas a constatar que en un convenio proyectado se dan los elementos objetivos y subjetivos comentados y que su contenido es adecuado a los fines perseguidos.

${ }_{47}$ Para LUQUE REGUEIRO, F., op. cit., pág. 1271, esto equivale a que la suscripción del convenio debe estar motivada por una razón de interés general, basarse en una identificación clara de los fines perseguidos y ser el instrumento más adecuado para garantizar su consecución.

48 Según LUQUE REGUEIRO, F., op. cit., pág. 1271, significa que si el convenio afecta a los gastos o ingresos públicos presentes y futuros, se deberá cuantificar y valorar sus repercusiones y efectos, y supeditarse al cumplimiento de los principios de estabilidad presupuestaria y sostenibilidad financiera, pero también podrán incorporarse los correspondientes análisis económicos de eventuales repercusiones indirectas en la economía (local, en este caso), en el ánimo de ilustrar sobre las consecuencias económicas globales del convenio.

49 LUQUE REGUEIRO, F., op. cit., pág. 1271, postula que los órganos gestores están compelidos a exponer las razones por las que el contenido obligacional del convenio no coincide con la naturaleza propia de los contratos sujetos al TRLCSP (en la actualidad, LCSP) o que su objeto no está comprendido en el de los contratos regulados en dicha Ley o en normas administrativas especiales, de modo que la memoria habrá de pronunciarse expresamente sobre si resulta de aplicación la exclusión prevista en el art. 4.1.c) y d) del TRLCSP (art. 6, apartados primero y segundo, de la LCSP, hoy en día) y, en definitiva, si es dable apartarse de los principios de concurrencia e igualdad que rigen la contratación pública. 
pósito pacificador de las relaciones urbanísticas, en cuanto permite llegar a acuerdos que resuelven controversias existentes o impiden su aparición ${ }^{50}$.

La necesidad y oportunidad, en el caso de convenios urbanísticos de planeamiento puede encontrar su fundamento en la justificación -exigida por el art. 36.2, regla a). $1^{\mathrm{a}}$, de la LOUA- de la mejora que la futura ordenación suponga para el bienestar de la población y fundarse en el mejor cumplimiento de los principios y fines de la actividad pública urbanística y de las reglas y estándares de ordenación regulados en la LOUA.

No obstante, hay supuestos en los que la necesidad del convenio urbanístico nace de la propia Ley; p. ej., la remisión expresa del art. 55.3 de la LOUA a la suscripción de un convenio urbanístico de planeamiento para el supuesto de sustitución por su valor en metálico de las cesiones del suelo correspondientes a la participación de la comunidad en las plusvalías (10\% del aprovechamiento lucrativo) en actuaciones de dotación en suelo urbano no consolidado (ex art. 45.2, letras B.c).

A igual razonamiento llegamos en el caso de los convenios urbanísticos de gestión cuando la LOUA recurre a ellos para el establecimiento y tramitación del sistema de actuación (p. ej., establecimiento del sistema de compensación por propietario único o unanimidad de los propietarios, ex arts. 130.1 y 138) o la cesión de suelo para dotaciones (art. 143.2).

Para que un convenio urbanístico quede excluido de las normas de contratación pública han de concurrir los siguientes requisitos: a) que no se intente alcanzar un beneficio en el mercado o éste sea de carácter residual; b) que se trate de un objetivo de interés público común a ambas partes, sin favorecer a ningún operador privado; y c) que se trate de una cooperación real, entre otros aspectos ${ }^{51}$.

c) Información pública ${ }^{52}$ :

Los convenios urbanísticos deben someterse al trámite de información pública antes de su aprobación (art. 25.1 del TRLSRU y art. 39.2 de la LOUA), mediante

50 SENDÍN GARCÍA, M. A., op. cit., págs. 62 y ss.

51 PFLUEGER TEJERO, E., op. cit., pág. 1254, al amparo de las Sentencias del Tribunal de Justicia de la Comunidad Europea de 10 de septiembre de 2009, asunto C-573/07 (TJCE 2009/272); de 19 de diciembre de 2012, asunto C-159/11 (TJCE 2014/437); y de 18 de diciembre de 2007, asunto C-220/06 (TJCE 2007/386)

${ }^{52}$ Para SENDÍN GARCÍA, M. A., op. cit., pág. 268 y ss., esto supone que su finalidad esencial no es la tutela de los intereses particulares de los interesados, sino permitir la accesibilidad de todos los posibles datos que puedan ser de utilidad a la hora de resolver el procedimiento, aunque no deja por ello de constituir también una medida que garantiza el derecho de la ciudadanía a defender su posición, permitiéndole hacer llegar su voz a la Administración. 
publicación de anuncio en el correspondiente boletín oficial de la provincia y tablón de anuncios municipal.

El anuncio señalará el lugar de exhibición, debiendo estar en todo caso a disposición de las personas que lo soliciten a través de medios electrónicos en la sede electrónica correspondiente, y determinará el plazo para formular alegaciones, que, en ningún caso podrá ser inferior a veinte días hábiles (art. 83, en relación con art. 30.2, de la LPACAP). La comparecencia en el trámite de información pública no otorga, por sí misma, la condición de interesado; no obstante, quienes presenten alegaciones u observaciones en este trámite tienen derecho a obtener de la Administración una respuesta razonada, que podrá ser común para todas aquellas alegaciones que planteen cuestiones sustancialmente iguales.

Aunque el art. 95.2 de la LOUA sólo prevé la información pública de los convenios urbanísticos de gestión en determinados $\operatorname{casos}^{53}$, inferimos, de la literalidad de los arts. 25.1 del TRLSRU (con carácter básico) y art. 39.2 de la LOUA, que todos ellos deben someterse a este trámite.

Cabe la posibilidad de que surjan modificaciones al texto inicial en este trámite y, por ende, sea necesario que ese texto transformado reciba también el visto bueno de la contraparte, pues pudiere ocurrir que con esas alteraciones ya no convenga a la persona que acuerda con la Administración ${ }^{54}$. La presentación para aprobación de una propuesta con contenido radical o sustancialmente diferente precisaría de un nuevo trámite de información pública.

d) Informes:

A los efectos de la resolución del procedimiento -de acuerdo con el art. 79.1 de la LPACAP-, se solicitarán aquellos informes que sean preceptivos por las disposiciones legales y los que se juzguen necesarios para resolver, citándose el precepto que los exija o fundamentando, en su caso, la conveniencia de reclamarlos. También el art. 172 del ROFRJEL ${ }^{55}$ prevé que en los expedientes informará el Jefe de la Dependencia a la que corresponda tramitarlos, exponiendo los antecedentes y disposiciones legales o reglamentarias en que funde su criterio. Ha de sumarse el informe específico de valoración de aprovechamientos especificado en el art. 30.2 de la LOUA, en

53 Los convenios que tengan por finalidad la elección o sustitución del sistema de ejecución, la fijación de sus bases, o incluyan entre sus compromisos algunos de los objetos establecidos para la reparcelación, según lo dispuesto en el artículo 100.2 de la LOUA, deberán ser sometidos antes de su firma a información pública por un plazo de veinte días.

${ }^{54}$ SENDÍN GARCÍA, M. A., op. cit., pág. 272 y ss.

55 R. D. 2568/1986, de 28 de noviembre, Reglamento de organización, funcionamiento y régimen jurídico de las Entidades locales. 
caso de permuta o sustitución en metálico, u otros que exigiera la normativa especial (bienes públicos, patrimonio histórico, etc.)

Cuando el convenio urbanístico sea susceptible de producir derechos de contenido económico, procede la emisión de informe en ejercicio de la función interventora, ex art. 214 del TRLHL ${ }^{56}$, que, además, habrá de analizar, entre otros aspectos, las exigencias del art. 48, apartados quinto y sexto, de la LRJSP, es decir, la sostenibilidad de los compromisos financieros asumidos, la capacidad de los suscriptores para financiarlos, así como que las aportaciones financieras comprometidas no superen los posibles gastos derivados de la ejecución del convenio.

Con la entrada en vigor de R. D. 128/2018, de 16 de marzo, por el que se regula el régimen jurídico de los funcionarios de Administración Local con habilitación de carácter nacional, se exige (art. 3.3), dentro de la función de asesoramiento legal preceptivo, la emisión de informe previo para la aprobación , modificación y derogación de convenios, si bien ese informe de la Secretaría podrá consistir en una nota de conformidad en relación con los informes que hayan sido emitidos por los servicios del propio Ayuntamiento y que figuren como informes jurídicos en el expediente (art. 3.4).

e) Aprobación:

El acuerdo de aprobación del convenio, al menos, identificará a los otorgantes, así como señalará su ámbito, objeto y plazo de vigencia (art. 30.2, regla $4^{\mathrm{a}}$ y art. 95.2, regla $\left.3^{\mathrm{a}}\right)$.

El acto administrativo de aprobación se notificará a los interesados cuyos derechos e intereses sean afectados, en los términos previstos en la normativa aplicable (art. 40.1 de la LPACAP).

En cuanto al órgano competente para la aprobación del convenio urbanístico, la LBRL señala de forma explícita al Pleno municipal para los municipios de régimen común -ex art. 22.2, letra c)- para la aprobación de los convenios que tengan por objeto la alteración de instrumentos urbanísticos ${ }^{57}$; por lo que cabe entender que para el resto de convenios urbanísticos es el Alcalde el órgano competente para su aprobación -en virtud del art. 21.1, letras j) o s)-, con posibilidad de delegar en la Junta de Gobierno Local. En cambio, no se pronuncia expresamente la LBRL para los

56 R. D. Leg. 2/2004, de 5 de marzo, Texto refundido de la Ley reguladora de las haciendas locales.

57 ARIAS MARTÍNEZ, M. A., op. cit., pág. 262, razona: "Por lo que se refiere a la Administración Local, la competencia le corresponde al Alcalde en ejercicio de sus funciones de dirección de gobierno y Administración municipal y representación del ayuntamiento. Asimismo, la LRBRL atribuye al pleno del ayuntamiento la aprobación de los convenios de fusión de municipios (art. 13.6). También le corresponde al Pleno municipal la aprobación de los convenios urbanísticos que vayan a alterar instrumentos de planeamiento (art. 22.2)." 
municipios de gran población. Pese a que el art. 19.3 de la LBRL indica que será de aplicación el régimen común para lo no previsto en el Título X (dedicado a los municipios de gran población), sin embargo, en esta última sede, el art. 124.4.ñ) atribuye expresamente la competencia residual al Alcalde, así que no apreciamos la existencia de laguna jurídica que debiera ser resuelta con remisión al régimen común.

La STSJ del País Vasco de 8 de marzo de 201758, que resuelve el recurso de apelación interpuesto contra la denegación de medida cautelar, no aprecia de forma incontrovertible el fumus boni iuris alegado por la apelante fundado en la competencia del Pleno (y no de la Junta de Gobierno Local) para la aprobación del convenio urbanístico (ex art. 22.2, letra c, de la LBRL), ante la oposición del Ayuntamiento de San Sebastián y la parte codemandada, que defienden que no es aplicable a los municipios con régimen de gran población.

Ahora bien, encontramos pronunciamientos en la doctrina que sostienen que corresponde a la Junta de Gobierno Local la aprobación de todos los convenios urbanísticos en municipios de gran población, con fundamento en el art. 127.1, letra d), de la LBRL, y por consiguiente, abogan por que el legislador, con una voluntad clara de limitación a esos actos, confiere al Pleno únicamente la aprobación inicial

58 JUR 2017/147699.

Alega la recurrente que concurre a su favor el fumus boni iuris, por cuanto el artículo 22.2.c) de la LBRL en la redacción dada por el número 1 de la disposición adicional novena del TRLSRU, expresamente atribuye al Pleno la competencia de aprobación de los convenios que tengan por objeto la alteración de cualquiera de los instrumentos y planes de ordenación urbanística, resultando que el artículo 127 de la LBRL no atribuye a la Junta de Gobierno Local competencia para la aprobación de los convenios urbanísticos.

El Ayuntamiento de San Sebastián demandado niega, sin embargo, que concurra el fumus que la apelante pretende, por cuanto la reforma de la LBRL operada por la disposición adicional novena de la Ley 8/2007, de 28 de mayo, atribuyó al Pleno la competencia de aprobación de los convenios urbanísticos en los municipios de régimen común, al modificar el artículo 22.2.c) LBRL pero no introdujo una previsión análoga para los municipios de gran población.

La parte codemandada que se opone rechaza el fumus invocado razonando que resulta aplicable el régimen de los municipios de gran población previsto por el Título X LBRL y no el régimen general al que alude la recurrente, resultando competente la Junta de Gobierno Local para la aprobación del convenio, puesto que el artículo 123 la excluye expresamente de las competencias del pleno.

No obstante, el órgano jurisdiccional no se pronuncia sobre este aspecto que remite a su resolución en sentencia sobre el fondo, con la siguiente explicación: "Finalmente, hemos de decir que no concurre en favor de la apelante la apariencia de que litiga con razón, con el carácter diáfano e incontrovertible que exige la doctrina jurisprudencial para que el fumus pueda decantar el juicio de ponderación de intereses, en cuanto postula la incompetencia de la funta de Gobierno local por la razón de que el artículo 22.2.c) LBRL, en la redacción dada por el número 1 de la disposición adicional novena del Real Decreto Legislativo siete/2015, de 30 de octubre, atribuye expresamente al pleno la competencia de aprobación de los convenios que tengan por objeto la alteración del planeamiento, toda vez que, frente a dicho planteamiento las apeladas alegan que dicha reforma modificó únicamente el régimen de los municipios de régimen común pero no introdujo una previsión análoga para los municipios de gran población. Se trata por tanto de una cuestión que ha de ser resuelta en sentencia, y que no permite un pronunciamiento en esta pieza sin riesgo de prejuzgar." 
del planeamiento general y la aprobación que ponga fin a la tramitación municipal de los planes y demás instrumentos de ordenación (art. 123.1, letra i) ( $^{59}$.

En lo que respecta a otras Comunidades Autónomas, las normas urbanísticas de Cantabria ${ }^{60}$, Castilla-La Mancha ${ }^{61}$, Madrid $^{62}$ y Murcia ${ }^{63}$ otorgan al Pleno la competencia para aprobar los convenios urbanísticos. En Aragón, sin embargo, el Alcalde es competente para aprobar los convenios de gestión y corresponde al Pleno la aprobación de los convenios urbanísticos de planeamiento ${ }^{64}$. Asturias requiere la autorización del Pleno para los convenios que comporten una modificación urbanística parcial ${ }^{65}$ y, en Canarias, la competencia corresponde al mismo órgano que la ostente para modificar el planeamiento y al Pleno para aquéllos convenios que no tengan tal objeto ${ }^{66}$.

A nuestro juicio, podemos entender que los convenios urbanísticos de gestión constituyan instrumentos de gestión urbanística y, por tanto, sea la Junta de Gobierno Local en los municipios de gran población la que los apruebe, ex art. 127.1.d) de la LBRL. En cuanto a los convenios de planeamiento, a pesar de no estar incluidos en el listado del art. 7 de la LOUA (en consecuencia, no están subsumidos en las competencias sobre aprobación de instrumentos urbanísticos ostentadas por la Junta de Gobierno Local y el Pleno, respectivamente), consideramos de poca lógica atribuir

59 En este sentido, ETXEZARRETA VILLALUENGA, J. C., "Los convenios urbanísticos", en Derecho urbanístico del País Vasco, Ed. El Consultor de los Ayuntamientos, Madrid (2008); y OCHOA GÓMEZ, M. P., Los convenios urbanísticos. Limites a la figura redentora del urbanismo, Ed. El Consultor de los Ayuntamientos, Madrid (2006), donde cita a CHOLBI CACHÁ, F. A., quien, con reservas, esboza la posibilidad de apoyar la aprobación en la cláusula residual de competencias de la Alcaldía.

En la Guía furídica de Wolters Kluwer, Convenios urbanísticos, se inclinan por atribuir la competencia de aprobación de convenios urbanísticos a la Junta de Gobierno Local, al amparo de lo dispuesto en el art. 127.1.d) de la LBRL

http:/ / guiasjuridicas.wolterskluwer.es/Content/Documento.aspx?params =H4sIAAAAAAAEAMtMSbF1jTAAAUMjQ1NTtbLUouLM_DxbIwMDCwNzAwuQQGZapUt-ckhlQaptWmJOcSoA6yZQ3TUAAAA=WKE

60 Arts. 261 y 262 de Ley de Cantabria 2/2001, de 25 de junio, de ordenación territorial y régimen urbanístico del suelo de Cantabria.

${ }_{61}$ Art. 12 del Decreto Legislativo 1/2010, de 18 de mayo, del Texto refundido de la Ley de ordenación del territorio y de la actividad urbanística.

62 Art. 247.4 de la Ley 9/2001, de 17 de julio, del Suelo de la Comunidad de Madrid.

63 Art. 182.6 de la Ley 13/2015, de 30 de marzo, de ordenación territorial y urbanística de la Región de Murcia.

64 Arts. 101.2 y 102.3 del Decreto Legislativo 1/2014, de 8 de julio, del Gobierno de Aragón, Texto refundido de la Ley de urbanismo de Aragón.

65 Art. 213 del Decreto Ley 1/2004, Texto refundido de las disposiciones legales vigentes en materia de ordenación del territorio y urbanismo

66 Art. 292 de Ley 4/2017, de 13 de julio, del suelo y de los espacios naturales protegidos de Canarias. 
la aprobación de aquéllos, de forma residual, al Alcalde, habida cuenta de que es la Junta de Gobierno Local la que aprueba los proyectos de instrumentos de ordenación urbanística (art. 127.1, letra c de la LBRL) y pudiera, así, ocurrir que se le de virtualidad a un convenio urbanístico cuyos efectos en el planeamiento terminen, casi inmediatamente, con la inadmisión a trámite por parte de la Junta de Gobierno Local. Nos inclinamos, consecuentemente, por que, al menos, sea este último órgano municipal, en Andalucía, el que apruebe los convenios urbanísticos de planeamiento (si no, el Pleno, atendiendo a la titularidad de la competencia si el convenio urbanístico afectare al planeamiento general), aunque sería recomendable que lege ferenda se aclarase tal extremo.

En este sentido, advertimos de que la disposición adicional segunda, apartado cuarto, de la LCSP, señala a la Junta de Gobierno Local como órgano de contratación competente en los municipios de gran población (salvo para la aprobación de pliegos de cláusulas administrativas generales, que corresponde al Pleno) ${ }^{67}$. En esta disposición podría, por tanto, fundamentarse, para estos municipios andaluces, la competencia de la Junta de Gobierno Local en lo que atañe a la aprobación del convenio urbanístico, ya sea por aplicación del art. 4 de la LCSP (si bien, para resolver dudas y lagunas en los negocios jurídicos excluidos de esta Ley, remite a la aplicación sólo de sus principios) ya sea por analogía.

\section{f) Firma:}

Los convenios se perfeccionan por la prestación del consentimiento de las partes (art. 48.8 de la LRJSP) ${ }^{68}$.

Los arts 21.1.b) y 124.4.a) de la LBRL atribuyen al Alcalde la representación del Ayuntamiento (en régimen común y de gran población, respectivamente), además de la más concreta competencia reconocida en el art. 41.12 del ROFRJEL para suscribir documentos. No obstante, podrá actuar directamente o mediante delegación del ejercicio de la competencia en un concejal (art. 9 de la LRJSP, 21.3 y 124.5 de la LBRL, y arts. 43 y ss. del ROFRJEL) ${ }^{69}$.

67 Tal condición de órgano de contratación de la Junta de Gobierno Local en los municipios de gran población también se reconocía por el derogado TRLCSP (disposición adicional segunda, apartado tercero).

68 ARIAS MARTÍNEZ, M. A., op. cit., pág. 264, apunta que los convenios se perfeccionan válidamente por la concurrencia de las manifestaciones de voluntad y, desde ese momento, ya se puede hablar de despliegue de una serie de efectos que vinculan a las partes a un comportamiento conforme a las exigencias de la buena fe, de respeto al convenio mismo y de la situación de dependencia que se ha creado, en la que las partes tienen una confianza digna de protección.

69 LUQUE REGUEIRO, F., op. cit., pag. 1263, subraya que, en el caso de sujetos públicos, sólo podrán firmar aquéllos que, según sus propias normas de distribución de atribuciones, ostenten competencia para ello, bien directamente o por delegación. 
Para la actuación asistida del órgano competente en la firma del convenio urbanístico, conforme a lo establecido en el art. 92.1 de la LBRL y arts. 1 a 3 del R. D. 128/2018, de 16 de marzo, de régimen jurídico de los funcionarios de Administración local con habilitación de carácter nacional, las funciones públicas necesarias de fe pública y asesoramiento legal preceptivo corresponden a estos funcionarios municipales.

La capacidad de obrar ante las Administraciones públicas se reconoce, ex art. 3 de la LPACAP, a las personas físicas o jurídicas que la ostenten con arreglo a las normas civiles (arts. 29, 30, 35 y 322 del CG, y demás normativa concordante), cuyo régimen de representación está regulado en el art. 5 de la LPACAP ${ }^{70}$.

La falta de ratificación y firma del convenio por la Administración determina su falta de validez, quedando su valor reducido a una mera declaración de intenciones ${ }^{71}$.

g) Inscripción y depósito en el Registro administrativo de instrumentos de planeamiento, convenios urbanísticos y de los bienes y espacios catalogados, en los términos regulados en los arts. 30.2.4 y 95.2.3 $3^{\mathrm{a}}$ de la LOUA, en relación con el art. 41.3 , y Decreto 2/2004, de 7 de enero, por el que se regulan los registros administrativos de instrumentos de planeamiento, de convenios urbanísticos y de los bienes y espacios catalogados, y se crea el Registro autonómico.

h) Publicación:

El acuerdo de aprobación del convenio urbanístico se publicará en el Boletín Oficial de la Provincia con expresión, al menos, de haberse procedido a su depósito en el Registro administrativo e identificación de sus otorgantes, objeto, situación y emplazamiento de los terrenos afectados (art. 86.2 de la LPACAP, art. 25.1 del TRLSRU, así como arts. 30.2.4 y 95.2.3 ${ }^{\mathrm{a}}$, en relación con el art. 41.3, de la LOUA). La falta de publicación supone, en su caso, la ineficacia del convenio ${ }^{72}$.

El Ayuntamiento debe tener a disposición de los ciudadanos que lo soliciten copias completas de los convenios urbanísticos (art. 70 ter, apartado primero de la LBRL).

i) Remisión al Tribunal Cuentas:

70 LUQUE REGUEIRO, F., op. cit., pág. 1263, explica que los sujetos intervinientes han de ostentar la adecuada capacidad, representación y competencia. Cuando se trate de sujetos privados sólo podrán firmar tales instrumentos las personas físicas que, según sus Estatutos, o en función de los correspondientes apoderamientos, ostenten la representación de la persona jurídica.

71 SENDÍN GARCÍA, M. A., op. cit., pág. 281.

72 SENDÍN GARCÍA, M. A., op. cit., pág. 283. 
Los convenios cuyos compromisos económicos asumidos superen los 600.000 euros $^{73}$ deberán remitirse electrónicamente al Tribunal de Cuentas u órgano externo de fiscalización de la Comunidad Autónoma, según corresponda, dentro de los tres meses siguientes a su suscripción, así como se comunicarán las modificaciones, prórrogas, variaciones de plazos, alteración de importes de los compromisos económicos asumidos y su extinción (art. 53 de la LRJSP) ${ }^{74}$.

\section{j) Inscripción en el Registro de la Propiedad ${ }^{75}$ :}

Podrán hacerse constar en el Registro de la Propiedad, en la forma y con los efectos dispuestos por la legislación reguladora de éste (Ley Hipotecaria y R. D. 1093/1997, de 4 de julio, Reglamento hipotecario urbanístico), los actos firmes de aprobación de los expedientes de ejecución de la ordenación urbanística en cuanto supongan la modificación de las fincas registrales afectadas por el instrumento de ordenación, la atribución del dominio o de otros derechos reales sobre las mismas o el establecimiento de garantías reales de la obligación de ejecución o de conservación de la urbanización y de las edificaciones, así como cualquier otro acto administrativo que, en desarrollo de los instrumentos de ordenación o ejecución urbanísticos modifique, desde luego o en el futuro, el dominio o cualquier otro derecho real sobre fincas determinadas o la descripción de éstas (art. 65.1 del TRLSRU). Con mayor concreción, el art. 177.1, letra a), de la LOUA menciona, como acto inscribible, la aprobación de convenios urbanísticos cuando supongan la alteración de la descrip-

73 Idéntica cantidad a la reflejada en el art. 335.1 de la LCSP para los contratos de obras, concesiones de obras, concesiones de servicios y acuerdos marco (anteriormente, art. 29 del TRLCSP, en términos parecidos).

74 Señala ARIAS MARTÍNEZ, M. A., op. cit., pág. 277, que no constituye un requisito de eficacia del convenio, es una obligación legal independiente que no se ve afectada por un eventual retraso en la publicación o registro del convenio.

En palabras de LADO CASTRO-RIAL, C., Régimen jurídico..., RECUERDA GIRELA, M. A. (Dir.), op. cit., pág. 1283 y ss., supone la elevación a norma de rango legal de la previsión contenida en la Resolución de 19 de diciembre de 2013, de la Presidencia del Tribunal de Cuentas, por la que se publica el Acuerdo del Pleno de 28 de noviembre de 2013, sobre la Instrucción general relativa a la remisión telemática al Tribunal de Cuentas de los extractos de los expedientes de contratación y de las relaciones de contratos, convenios y encomiendas de gestión celebrados por las entidades del sector público estatal y autonómico.

75 ZURITA JIMÉNEZ, M., en "Convenios urbanísticos en la LOU de Andalucía”, Directivos Construcción, n 163 (enero 2004), Ed. Wolters Kluwer, Madrid (2004), pág. 39, distingue las obligaciones de cesión de terrenos de las obligaciones de ejecución de obras. En las primeras, para poder operar el convenio urbanístico como título de transmisión inscribible en el Registro de la Propiedad, enumera las siguientes determinaciones: a) la naturaleza, situación y linderos de los inmuebles a los cuales afecte el derecho que deba inscribirse, y su medida superficial, nombre y número, si constan en el título; b) la naturaleza, la extensión y condiciones suspensivas o resolutorias, si las hay, del derecho que se inscriba y su valor, cuando constare en el título; c) el derecho sobre el cual se constituya el que sea objeto de la inscripción; d) la persona natural o jurídica a cuyo favor se debe hacer la inscripción; y e) la persona de quien procedan inmediatamente los bienes o derechos que deban inscribirse. 
ción registral, del dominio o de cualquier otro derecho real de la finca o fincas objeto del mismo.

Tendrán acceso al Registro de la Propiedad (aunque el contenido del convenio no sea susceptible de inscripción) las garantías reales (p. ej., hipoteca) que se hayan impuesto sobre fincas registrales para asegurar el cumplimiento de los compromisos asumidos en el convenio ${ }^{76}$.

\section{LA EXTINGIÓN DE LOS CONVENIOS URBANÍSTICOS}

\section{Supuestos de extinción}

Los supuestos de extinción de los convenios están enumerados en el art. 51 de la LRJSP, que distingue entre: a) cumplimiento de las actuaciones que constituyen su objeto (que será el modo normal u ordinario de extinción), y b) por incurrir en causas de resolución.

Como causas de resolución, el apartado segundo del art. 51 de la LRJSP contempla las siguientes ${ }^{77}$ : $\operatorname{rroga}^{78}$.

a) Transcurso del plazo de vigencia del convenio sin haberse acordado su pró-

b) Acuerdo unánime de todos los firmantes ${ }^{79}$.

c) Incumplimiento de las obligaciones y compromisos asumidos por parte de alguno de los firmantes ${ }^{80}$.

${ }^{76}$ En este sentido, SENDÍN GARCÍA, M. A., op. cit., pág. 292.

77 En opinión de LUQUE REGUEIRO, F., op. cit., pág. 1276 y ss., este precepto da cobertura y solución ope legis a la extinción de aquellos convenios que, por defectos en su redacción o falta de previsión de las partes, omitan las eventualidades merecedoras de resolución y, por tanto, hace innecesaria su incorporación al contenido del convenio para su operatividad.

78 LUQUE REGUEIRO, F., op. cit., pág. 1276, piensa que, en puridad jurídica, la pérdida de vigencia del convenio no cabe considerarla en sentido estricto como una causa de resolución.

79 Llama la atención LUQUE REGUEIRO, F., op. cit., pág. 1278, sobre la circunstancia de que en ese momento la representación, capacidad y competencia de cada una de las partes no tiene por qué coincidir necesariamente con las personas fisicas que inicialmente firmaron el convenio. Asimismo, opina que el acuerdo unánime debe ser rubricado en un determinado instrumento, que cumpla los requisitos legales, donde las partes manifiesten que la ejecución se ha realizado a conformidad de todas ellas o que se opta por renunciar a la consecución del objeto (si es viable tal renuncia).

${ }^{80}$ LUQUE REGUEIRO, F., op. cit., pág. 1277, cuestiona que no se discrimine entre los incumplimientos graves o reiterados y los que no lo son, así como entre obligaciones principales y accesorias. 
d) Decisión judicial declaratoria de la nulidad del convenio ${ }^{81}$.

En nuestra opinión, también supondría causa de resolución la declaración de nulidad por vía administrativa, a través del correspondiente procedimiento de revisión (art. 106 de la LPACAP).

SENDÍN ${ }^{22}$ remite a los supuestos de invalidez previstos para los contratos administrativos (arts. 38 y ss. de la LCSP, en la actualidad) y suma, como causa específica, la imposición de obligaciones más gravosas que las previstas en la Ley.

Mantiene también que la declaración de nulidad dará lugar a la devolución recíproca de las prestaciones o, no siendo esto posible, a la devolución de su valor, pues determina la restitución de las partes a la situación en la que se encontraban antes de su celebración, de tal forma que recuperan los derechos y potestades que le correspondan por atribución legal ${ }^{83}$.

Entendemos que, de concurrir la nulidad parcial de sólo alguna o algunas estipulaciones del convenio urbanístico, conforme a lo dispuesto en el art. 51 de la LPACAP, podrá decidirse, si procede, la conservación del contenido que se hubiera mantenido igual de no haberse cometido la infracción.

${ }^{81}$ Alerta ARIAS MARTÍNEZ, M. A., op. cit., págs.. 277 y ss., de que también pueden verse afectados por un vicio de invalidez (nulidad o anulabilidad) cualquiera de los actos administrativos que traen causa del convenio o que hayan servido de soporte.

Para LUQUE REGUEIRO, F., op. cit., pág. 1278, no constituye una causa de resolución, sino una forma de extinción, y hubiera sido conveniente especificar cuáles son concretamente los vicios susceptibles de provocar tal nulidad, pues pueden concurrir vicios menos severos de anulabilidad.

82 SENDÍN GARCÍA, M. A., op. cit., pág. 229 y ss, donde hace un análisis extenso de la invalidez del convenio.

Este autor (págs.. 123 y ss) señala también, como límites y posibles causas de invalidez del convenio urbanístico: la falta de consentimiento, objeto incierto o imposible, ausencia de causa, incumplimiento de la legalidad (normas imperativas, principio de jerarquía entre instrumentos de planeamiento, equilibrio económico de las prestaciones, prohibición de reservas de dispensación), no persecución del interés público, disponibilidad de las potestades administrativas, desatención del principio de eficacia y buena administración, exceso de competencia y desvinculación a los hechos determinantes (comprometerse a otorgar aquello que el ordenamiento jurídico sujeta a requisitos fácticos que no se dan o no otorgarlo por causa del convenio cuando se dan tales requisitos).

Ante una declaración de nulidad habrá de estarse a los postulados contenidos en el artículo 1303 del Código Civil en relación con la restitución. Efectivamente, en el mismo se establece que "declarada la nulidad de una obligación, los contratantes deben restituirse recíprocamente las cosas que hubiesen sido materia del contrato, con sus frutos, y el precio de los intereses...", añadiendo el artículo 1307 del mismo Código, para el supuesto en que no resultara posible la devolución de la cosa que el obligado "deberá restituir lo frutos percibidos y el valor que tenía la cosa cuando se perdió, con los intereses desde la misma fecha".

Así, ante un supuesto de nulidad de convenio urbanístico, la "consecuencia insoslayable de ello es la devolución de las cantidades recíprocamente entregadas, a tenor de lo establecido en los artículos 1303 y siguientes del Código Civil", como declara el Tribunal Supremo en Sentencia de 24 de marzo de 2003 (RJ 2003/2923).

83 SENDÍN GARCÍA, M. A., op. cit., págs. 246 y ss. 
e) Otra causa distinta de las anteriores prevista en el convenio ${ }^{84}$ o en otras leyes:

Respecto a aquellos convenios urbanísticos cuyo objeto verse sobre la tramitación de procedimientos administrativos (v. gr., innovaciones de planeamiento, ejecución de sistemas de actuación, reparcelación), consideramos conveniente recoger expresamente en el convenio, como un supuesto más de extinción, la terminación de los procedimientos por otras resoluciones distintas a la aprobatoria, esto es, por recaer de acuerdo denegatorio, desistimiento (recordemos que cabe por parte de la Administración, ex art. 93 de la LPACAP), renuncia, caducidad o causa sobrevenida ${ }^{85}$.

\section{Efectos de la extinción}

En caso de incumplimiento de obligaciones y compromisos (como causa de resolución), el art. 51.2.c) de la LRJSP regula el requerimiento a la parte incumplidora $^{86}$. El párrafo utiliza el verbo "podrá", con lo que surge la duda habitual de si ello significa que es una habilitación legal para la posible decisión libérrima de la parte cumplidora o un precepto con carácter de mandato. Abogamos por su carácter de mandato (dado el aspecto convencional de la institución, la presencia del mecanismo de seguimiento, vigilancia y control, la posible existencia de otras partes, así como la previsión de este trámite previo para la resolución, según la redacción del propio artículo), y, en consecuencia, por la inclusión del régimen de este requerimiento en el contenido del convenio.

La LRJSP, en ese caso, expone que cualquiera de las partes podrá notificar a la parte incumplidora un requerimiento para que cumpla en un determinado pla$\mathrm{zo}^{87}$ con las obligaciones o compromisos que se consideran incumplidos, que será comunicado al responsable del mecanismo de seguimiento, vigilancia y control de la ejecución del convenio y a las demás partes firmantes. Así pues, es importante que el convenio estipule el deber de efectuar el requerimiento y señale los plazos tanto

\footnotetext{
${ }_{84}$ Principio de libertad de pactos, según LUQUE REGUEIRO, op. cit., pág. 1279.

85 Arts. 84 y concordantes de la LPACAP.

86 La inclusión de este requerimiento en el texto de la Ley fue criticado en sede parlamentaria por
} el Grupo Parlamentario Izquierda Plural, en el Congreso de los Diputados, enmiendas n ${ }^{\circ} 90$ y 91 , porque "puede producir una fuerte inestabilidad en los convenios".

${ }^{87}$ Advierte ARIAS MARTÍNEZ, M. A., op. cit., pág. 272, de que el legislador no especifica ni exige una cierta proporcionalidad entre el tipo de incumplimiento, más o menos grave, y la amplitud del plazo concedido para cumplir las obligaciones no realizadas.

PIZARRO NEVADO, R., op. cit., pág. 149, critica que no se ha matizado la reacción en función de la gravedad del incumplimiento, ni se ha diferenciado entre los distintos tipos de convenios administrativos, previéndose una solución única, cualquiera que sea la modalidad empleada y la naturaleza jurídica del sujeto que sufre el incumplimiento. Ante ello, plantea que en los convenios con sujetos de Derecho Privado, en consideración a la entidad del incumplimiento del particular, se permita que la Administración acuda a los mecanismos de ejecución forzosa para exigir el cumplimiento de las obligaciones establecidas. 
para el cumplimiento de la obligación como para la notificación al responsable del mecanismo y a las otras partes, además de la, más que recomendable, posibilidad de formular alegaciones durante tal período.

Transcurrido el plazo indicado en el requerimiento, de persistir el incumplimiento, la parte que lo dirigió notificará a las demás firmantes la concurrencia de la causa de resolución y se entenderá resuelto el convenio ${ }^{88}$. Habida cuenta de que la Ley prevé que el incumplimiento podrá conllevar la indemnización de los perjuicios causados, si así se hubiera previsto, alentamos también al establecimiento del quantum o de las bases para su cálculo en el convenio urbanístico ${ }^{89}$.

${ }_{88}$ Opina ARIAS MARTÍNEZ, M. A., op. cit., pág. 273, que, en este supuesto, quien declara la resolución del contrato y, por lo tanto, la extinción del mismo, es una de las partes; sin embargo, ello no impide a las otras partes impugnar esta decisión ante los tribunales de la jurisdicción contencioso-administrativa.

A juicio de PIZARRO NEVADO, R., op. cit., pág. 150, parece reconocerse a cualquiera de las partes la facultad de decidir si se ha cumplido o no adecuadamente y, por tanto, si se resuelve el convenio, lo que puede generar una indeseable inestabilidad y convertirse en un foco de conflictividad. Señala que se deja sin sentido la intervención del mecanismo de seguimiento, vigilancia y control de la ejecución del convenio, al que simplemente se notificaría que se ha efectuado el requerimiento, pero sin concederle aparentemente intervención en la decisión resolutoria. En consecuencia, propone que, para evitar la conflictividad, se perfile suficientemente en los convenios cuáles son los mecanismos de seguimiento y control de la ejecución de los compromisos adquiridos por los firmantes, incorporando soluciones realistas y ágiles que no pasen necesariamente por la resolución.

PFLUEGER TEJERO, E., op. cit., pág. 1254, reseña que en los convenios no debe darse una situación de subordinación entre las partes, de modo que, como señala el Tribunal Supremo, en Sentencia de 15 de julio de 2003 (RJ 2003/6345), "a diferencia de los contratos administrativos ninguna de las partes tiene prerrogativas ni fuerza vinculante". Sin embargo, SENDÍN GARCÍA, M. A., op. cit., pág. 113, puntualiza que "en la concertación urbanística confluyen dos sujetos que están en situación de desigualdad, en cuanto la Administración, como poder público que es, está dotado de potestades públicas que le sitúan en una situación de superioridad”.

89 SENDÍN GARCÍA, M. A., op. cit., págs. 178 y ss., aduce que, de acuerdo con el principio de indisponibilidad, la Administración no puede ser compelida forzosamente a cumplir el convenio cuando puede desligarse lícitamente del mismo, ni cabe fijar medidas que presionen a la Administración para llegar al resultado pactado en el convenio, al aprobar los planes; de ahí que no debe admitirse el pacto de una penalidad que recaiga sobre la Administración. Por lo que, aunque el Ayuntamiento hubiese celebrado contrato en el que se obligaba a una determinada clasificación de los terrenos con un determinado aprovechamiento, si posteriormente considera que el interés público requiere una clasificación o aprovechamientos distintos, puede alterar el planeamiento sin que el convenio sea obstáculo.

La justificación de libertad en la posibilidad de desligarse de lo acordado -que no existe en el campo del Derecho Givil- tiene su justificación en que el urbanismo es una función pública y, como tal, indisponible e irrenunciable (STS 15 de marzo de 1997, RJ 1997/1677).

Los incumplimientos de un convenio urbanístico no son directamente exigibles, sino generadores de daños y perjuicios evaluables, a no ser que sus pactos se integren en instrumentos específicos del planeamiento que son los que tienen carácter normativo STSJ Cataluña de 26 enero de 2006 (JUR 2006\255592). 
Según SENDÍN ${ }^{90}$, el incumplimiento por la Administración de sus obligaciones derivadas del convenio urbanístico puede dar lugar a tres tipos de acciones: contractuales, de responsabilidad patrimonial y de enriquecimiento injusto.

En caso de incumplimiento por el particular, la Administración podrá hacer uso de sus poderes de decisión unilateral y ejecutoria para lograr su cumplimiento, recayendo sobre la persona que conviene la decisión de impugnar si no está de acuer$\mathrm{do}^{91}$. Es posible el establecimiento de cauciones o medidas de garantía en el convenio y, así, la STS de 16 de octubre de $2001^{92}$ admite la constitución de un aval ejecutable en caso de incumplimiento de la contraparte privada.

El cumplimiento y la resolución de los convenios darán lugar a su liquidación, en virtud del art. 52 de la LRJSP, con el objeto de determinar las obligaciones y compromisos de cada una de las partes ${ }^{93}$.

A tal fin, el precepto, para los compromisos financieros derivados del convenio, apunta que se entenderán cumplidos una vez realizados en los términos y a satisfacción de ambas partes (de todas, añadimos), de acuerdo con sus respectivas competencias. Para ello contempla dos reglas de compensación, dependiendo de que el importe de las actuaciones ejecutadas fuera inferior o superior, respectivamente, a los fondos percibidos. En el primer supuesto, conllevará el reintegro del exceso en el

$90 \quad$ SENDÍN GARCÍA, M. A., op. cit., págs.. 190 y ss. En sentido similar ARREDONDO GUTIÉRREZ, J., Los convenios urbanísticos, Ed. Comares, Granada (2003), pág. 88.

Ahora bien, SENDÍN distingue entre el incumplimiento culpable de la Administración y la resolución no culpable. En este último caso - p. ej., pactos relativos al ejercicio de potestades públicas indisponibles-, basta con el ejercicio diligente de lo pactado sin deber de obtener el resultado y, por lo tanto, sólo conlleva la resolución del convenio. Por el contrario, si acaece un incumplimiento culpable por la Administración, el perjudicado podrá escoger entre exigir el cumplimiento o la resolución de la obligación con el resarcimiento de daños y perjuicios con abono de intereses (art. 1124 del Código Civil), sin menoscabo de reclamación en vía administrativa por inactividad de la Administración (art. 29 de la Ley 29/1988, de 13 de julio, de la Jurisdicción Contencioso-administrativa), aunque habrá casos en que no sea posible el cumplimiento (potestades públicas indisponibles) o la devolución de prestaciones (deberes legales del sujeto privado). Matiza, no obstante, este autor el caso en que resulte del convenio una ilegalidad o se detecte $a$ posteriori un incumplimiento del interés público, que pueden justificar el apartamiento de la Administración sin indemnización al particular, así como la actuación de la Administración ajena al principio de buena fe, que dará lugar a indemnización. Serán indemnizables los daños efectivos, pero no la mera expectativa de aprovechamiento urbanístico, ni las prestaciones constitutivas de meros deberes legales gratuitos por imperio de la Ley.

91 SENDÍN GARCÍA, M. A., op. cit., págs.. 216 y ss.

92 RJ 2001/8381.

La STS de 26 de octubre de 2001 (RJ 2001/8381) proclama la posibilidad de que las partes pacten la constitución de aval y su ejecución por la Administración, sin más trámite que el requerimiento al sujeto privado del cumplimiento de la obligación correspondiente.

93 Con el fin de evitar el enriquecimiento injusto de cualquiera de las partes, como sostiene ARIAS MARTÍNEZ, M. A., op. cit., pág. 275. 
plazo máximo de un mes desde la aprobación de la liquidación, que, de no hacerse efectivo en ese plazo, originará el deber de abonar a las partes, en un mes desde ese momento, el interés de demora correspondiente (el resultante de las disposiciones de carácter general reguladoras del gasto público y de la actividad económico-financiera del sector público). Si fuera superior, el resto de partes, en el plazo de un mes desde la aprobación de la liquidación, deberá abonar a la parte que haya realizado la ejecución la diferencia correspondiente, hasta el límite máximo comprometido por cada una de ellas, sin que exista el derecho de exigir por cualquiera de las partes cuantía que supere el susodicho límite a otra de ellas ${ }^{94}$.

Apreciamos que, en determinados casos (p. ej., ciertos convenios urbanísticos de gestión) podría darse esta fase de liquidación en un convenio urbanístico, por lo que debería establecerse el régimen jurídico de la liquidación en el texto del convenio (representación de las partes, convocatorias, plazos, valoración económica, régimen de mayorías, recursos, ejecución en supuestos de incumplimiento, etc.).

Introduce, por último, la LRJSP (art. 52.3) la posibilidad de prorrogar el plazo para la continuación y finalización de las actuaciones en curso que se consideren oportunas ante la concurrencia de una causa de resolución. A la sazón, las partes, a propuesta de la comisión de seguimiento, vigilancia y control del convenio o del responsable del mecanismo, en su caso, podrán acordar la continuación y finalización con el establecimiento de un plazo improrrogable para su terminación, transcurrido el cual habrá de realizarse la liquidación. En nuestra opinión, sería recomendable insertar en el texto del convenio urbanístico tal previsión con determinación del plazo (al menos, máximo) y una somera regulación del procedimiento correspondiente ${ }^{95}$.

94 Por esta razón, ARIAS MARTÍNEZ, M. A., op. cit., pág. 275, propone que si la ejecución del convenio supone un coste final mayor que el inicialmente previsto, la parte que se encargue de dicha ejecución debe promover primeramente la modificación del convenio antes de aprobar el aumento del gasto.

95 LUQUE REGUEIRO, F., op. cit., pág. 1267, entiende, que ante lo normado en el art. 52 de la LRJSP respecto a la liquidación del convenio y la posible continuación de las actuaciones en curso de ejecución, debe prevalecer lo pactado por las partes, en aplicación y con los límites del art. 1255 del Código Civil. 


\section{BIBLIOGRAFÍA}

ARREDONDO GUTIÉRREZ, J., Los convenios urbanísticos, Ed. Comares, Granada (2003)

BENSUSAN MARTÍN, M. P., "La nueva regulación de los convenios: la conversión en derecho positivo de una práctica administrativa", Revista Andaluza de Administración Pública, $\mathrm{n}^{\circ}$ 96, Ed. IAAP, Sevilla (2016)

CAMPOS ACUÑA, C. (Dir.), Comentarios a la Ley 39/2015 de procedimiento administrativo común de las Administraciones públicas, Ed. Wolters Kluwer, Madrid (2017)

CAMPOS ACUÑA, C. (Dir.), Comentarios a la Ley 40/2015 de Régimen Furídico del Sector Público, Ed. Wolters Kluwer, Madrid (2017)

CANO MURCIA, A., Teoría y práctica del convenio urbanístico, Ed. Aranzadi, Cizur Menor (2005)

ETXEZARRETA VILLALUENGA, J. C., "Los convenios urbanísticos", en Derecho urbanístico del País Vasco, Ed. El Consultor de los Ayuntamientos, Madrid (2008)

GOZÁLBEZ PEQUEÑO, H. (Dir.), El nuevo régimen jurídico del sector público, Ed. Wolters Kluwer, Madrid (2016)

GRANADOS RODRÍGUEZ, J. F., "La dirección pública profesional y la creación de órganos directivos en las administraciones locales de régimen común", Revista Iberoamericana de Gobierno Local, nº 5, Ed. CIGOB, Granada (2013)

GRANADOS RODRÍGUEZ, J. F., "La revisión de actos nulos mediante el ejercicio de la acción pública en materia de urbanismo: una herramienta más para combatir las ilegalidades urbanísticas", Revista de Derecho urbanístico y medio ambiente, $\mathrm{n}^{\circ}$ 228, Ed. Montecorvo, Madrid (2006)

Guía Furídica de Wolters Kluwer, Convenios urbanísticos, http://guiasjuridicas.wolterskluwer.es/Content/Documento.aspx?params=H4sIAAAAAAAEAMtMSbFljTAAAUMjQ1NTtbLUouLM_DxbIwMDGwNzAwuQQGZapUt-ckhlQaptWmJOcSoA6yZQ3TUAAAA=WKE

LAGO NÚÑEZ, G., Los convenios urbanísticos de Andalucía (2010), http://www. academia.edu/8618441/LOS_CONVENIOS_URBAN\%C3\%8DSTICOS_EN_ ANDALUC $\% \mathrm{C} 3 \% 8 \mathrm{DA}$

MÚZQUIZ JIMÉNEZ I., "Los convenios administrativos en la Ley 40/2015 y su impacto sobre los convenios urbanísticos", Revista del sector inmobiliario Inmueble, $\mathrm{n}^{\circ}$ 171, Ed. Difusión Jurídica y Temas de Actualidad, Madrid (2017) 
OCHOA GÓMEZ, M. P., Los convenios urbanisticos. Limites a la figura redentora del urbanismo, Ed. El Consultor de los Ayuntamientos, Madrid (2006)

RECUERDA GIRELA, M. A. (Dir.), Régimen jurídico del Sector Público y Procedimiento Administrativo Común, Ed. Thomson Reuters, Cizur Menor (2016)

SENDÍN GARCíA, M. A., Régimen jurídico de los convenios urbanísticos, Ed. Comares, Granada (2008)

VV.AA., Instituciones de procedimiento administrativo común. Novedades de la Ley 39/2015, Ed.Juruá, Lisboa (2016)

ZURITA JIMÉNEZ, M., "Convenios urbanísticos en la LOU de Andalucía”, Directivos Construcción, no 163 (enero 2004), Ed. Wolters Kluwer, Madrid (2004) 